\title{
Mycoplasma capricolum subsp. capripneumoniae, the cause of contagious caprine pleuropneumonia, comprises two distinct biochemical groups
}

\author{
Zeina Soayfane $^{1}$, Bilal Houshaymi ${ }^{1}$ and Robin A.J. Nicholas ${ }^{2, *}$ \\ ${ }^{I}$ Microbiology Department, Lebanese University, Hadath Campus, Beirut, Lebanon \\ ${ }^{2}$ Consultant, The Oaks, Nutshell Lane, Upper Hale, Farnham, Surrey GU9 OHG, UK
}

\begin{abstract}
Mycoplasma capricolum subsp. capripneumoniae, the cause of the World Organisation of Animal Health- listed contagious caprine pleuropneumonia, is a member of the Mycoplasma mycoides cluster which comprises five pathogenic mycoplasmas of ruminants. These mycoplasmas are closely related immunologically and genetically which can lead to difficulties for differential diagnosis. The patterns of substrate metabolism of strains of $M$. $c$. capripneumoniae, gathered from diverse geographic regions, were studied by measurement of oxygen uptake rates. The strains fell into two major biochemical groups: one which only oxidised organic acids and glycerol and the other which could additionally metabolise sugars. Furthermore when DNA-DNA hybridisation tests were carried out these two groups of strains could be separated by their degree of DNA homology, the mean hybridisation value between members of the two groups was $86 \%$ well above the value of $70 \%$ normally used to indicate separate species. DNADNA hybridisation was also carried out between M. c. capripneumoniae strains and other members of the M. mycoides cluster. These experiments used labelled DNA from two representative subsp. capripneumoniae strains; these were 7/1a (organic acid-oxidising) and 4/2 LC (glucose-oxidising). The results showed a particularly close relationship of the glucose-oxidising strain to $M$. leachii strains.
\end{abstract}

Keywords: Mycoplasma capricolum subsp. capripneumoniae, Contagious caprine pleuropneumonia, Substrate metabolism, DNA-DNA hybridisation.

\section{Introduction}

Mycoplasma capricolum subspecies capripneumoniae is a member of Mycoplasma mycoides cluster (Cottew et al., 1987) which comprises five pathogens of ruminants including the mycoplasmas causing contagious bovine pleuropneumonia, contagious caprine pleuropneumonia (CCPP) and contagious agalactia which have been listed by the World Organisation for Animal Health because of their damaging socio-economic impacts. CCPP is characterised by respiratory distress, coughing, nasal discharge and severe fibrinous pleuropneumonia. It is a significant disease of goats in Africa, the Middle East and parts of Asia, and can cause mortality of up to $80 \%$ in immunologically naïve herds (Houshaymi et al., 2002). The members of the M. mycoides cluster show close genetic and immunological similarity which has led to difficulties for differential diagnosis (Leach $e t$ al., 1993).

A study of their substrate metabolism was first carried out by Abu-Groun et al. (1994) who showed that it was possible to differentiate and classify groups within the cluster by their patterns and kinetics of substrate utilisation. In that study, only one of four strains of $M$. c. capripneumoniae oxidised glucose; the other three gave no detectable oxygen uptake with glucose but did oxidise organic acids. These results were surprising since all strains of the very closely related $M$. $c$. capricolum and other members of the cluster tested oxidised glucose. However, for some of the cluster, $M$. mycoides subsp. mycoides (previously suffixed SC), $M$. leachii (previously named bovine serogroup 7) and $M$. c. capripneumoniae, only small numbers of strains were tested.

Pettersson et al. (1998) was the first to study the polymorphism patterns amongst 16S rRNA genes of $M$. c. capripneumoniae from diverse locations. While it appeared that the mycoplasma formed a homogenous group, a phylogenetic tree constructed by comparative analysis of the polymorphisms, revealed two distinct lines of descent. Other studies on evolutionary and genetic relationship between the members of the ' $M$. mycoides cluster' have been published over the last decade increasing our understanding of the molecular biology of these mycoplasmas (Manso-Silvan et al., 2007; Thiaucourt et al., 2011), less is known of the biochemistry of these mycoplasmas, in particular the patterns and kinetics of substrate utilisation.

In the work reported here, additional strains were included to investigate further the diversity of substrate utilisation with specific reference to $M . c$. capripneumoniae. 
In addition, DNA-DNA hybridisation was used to investigate the relationships between the strains and other members of the cluster. The aims of the work were to determine the genetic homogeneity amongst strains which might enable the subdivision of strains in accordance with the biochemical findings.

\section{Mycoplasma strains}

\section{Materials and Methods}

M. c. capripneumoniae strains used in this work were 19/2, 4/2LC (Oman), T3, T7, T9, T11 (Eritrea), Baringo, F38, G94/83 (Kenya) and 7/1a (Turkey). They were obtained from the strain bank of the Veterinary Laboratories Agency (now Animal and Plant Health Agency), Addlestone, UK. Their identity was confirmed by serological and molecular amplification methods (Houshaymi et al., 2002). The Mycoplasma bovis type strain NCTC 10131was included as a negative control in one hybridisation experiment.

\section{Biochemical studies}

Substrate oxidation was based on measurement of oxygen uptake, detected by changes in dissolved oxygen tension (DOT) using an oxygen electrode system as described by Miles and Agbanyim (1998). The sugars and organic acids tested as possible metabolic substrates included all those substrates previously shown to be oxidised by members of the $M$. mycoides cluster in the extensive study of Abu-Groun et al. (1994).

\section{Labelling of mycoplasma DNA with digoxigenin}

A small amount $(1 \mu \mathrm{g})$ of the reference DNA, extracted by the method of Bashiruddin (1998), to be labelled was digested with EcoRI enzyme at $37^{\circ} \mathrm{C}$ for 4 to $16 \mathrm{~h}$. The standard volume of the digestion mix was $20 \mu \mathrm{l}$. After digestion this was adjusted to $100 \mu \mathrm{l}$ with deionised water and the digest was then extracted with an equal volume of phenol/chloroform (50:50). The DNA in the aqueous phase was then precipitated with 2 volumes of cold ethanol and collected by centrifugation at $12,000 \mathrm{rpm}$ for $20 \mathrm{~min}$. The DNA pellet was air dried for $30 \mathrm{~min}$ and then dissolved in $15 \mu \mathrm{l}$ of TE buffer. Prior to labelling, the DNA was denatured by heating in a boiling water bath for $5 \mathrm{~min}$ and then cooling rapidly on ice.

The denatured DNA was labelled overnight at $37{ }^{\circ} \mathrm{C}$ using $2 \mu \mathrm{l}$ hexanucleotide mixture, $2 \mu$ digoxygeninlabelled dNTP and $1 \mu \mathrm{l}$ Klenow enzyme (Roche,Welwyn Garden City, UK).

The labelling reaction was stopped by adding $2 \mu \mathrm{l}$ of 0.2 M EDTA. The labelled DNA was then precipitated by adding $2.5 \mu \mathrm{l}$ of $4 \mathrm{M} \mathrm{LiCl}$ and $75 \mu \mathrm{l}$ of cold ethanol. The mixture was maintained at $-20{ }^{\circ} \mathrm{C}$ for $2 \mathrm{~h}$ and the precipitate was then collected as before and air-dried for $30 \mathrm{~min}$. The DNA was re-dissolved in $50 \mu \mathrm{l}$ of TE buffer.

\section{Preparation of DNA-loaded membranes for hybridisation}

Target DNA to be analysed was blotted onto Hybond $\mathrm{N}^{+}$charged nylon membranes (Amersham International, Amersham, UK), using a standard vacuum dot blot apparatus. The wells of the apparatus were loaded with $3 \mu \mathrm{g}$ of purified genomic DNA (contained in approximately $10 \mu \mathrm{TE}$ buffer). The membrane was applied for 5 min to filter paper wetted with denaturation buffer $(1.5 \mathrm{M} \mathrm{NaCl}$ and $0.5 \mathrm{M}$ $\mathrm{NaOH})$ and then to filter paper wetted with neutralisation buffer $(0.5 \mathrm{M}$ Tris- $\mathrm{HCl}, \mathrm{pH} 8.0,3 \mathrm{M}$ $\mathrm{NaCl}$ ) for a further $5 \mathrm{~min}$. Finally, the membrane was exposed (after air drying) to a UV trans-illuminator $(312 \mathrm{~nm})$ for $4 \mathrm{~min}$ to immobilise the DNA.

\section{DNA hybridisation}

Hybond $\mathrm{N}^{+}$membranes loaded with target DNA were hybridized overnight with $100 \mathrm{ng}$ of freshly denatured, digoxigenin-labelled reference DNA at $68{ }^{\circ} \mathrm{C}$. The protocol adopted was as described for the DIG Labelling and Detection Kit by the manufacturer (Roche, Welwyn Garden City, UK). The hybridisation buffer $(25 \mathrm{ml})$ was $5 \mathrm{x}$ SSC, $0.1 \%(\mathrm{w} / \mathrm{v}) \mathrm{N}-$ lauroylsarcosine, $0.02 \%(\mathrm{w} / \mathrm{v}) \mathrm{SDS}$, and $1 \%(\mathrm{w} / \mathrm{v})$ blocking reagent. Blocking reagent was prepared as a stock of $10 \%(\mathrm{w} / \mathrm{v})$ solution of this reagent (Roche, Welwyn Garden City, UK) dissolved in buffer A (0.1 $\mathrm{M}$ maleic acid and $0.015 \mathrm{M} \mathrm{NaCl}, \mathrm{pH} 7.0)$ by constantly stirring on a heating block $\left(65^{\circ} \mathrm{C}\right)$ for $1 \mathrm{~h}$ and then autoclaving and storing at $4{ }^{\circ} \mathrm{C}$. SSC was prepared as a stock solution of $20 \mathrm{x}$ SSC $(3 \mathrm{M} \mathrm{NaCl}$ and $0.3 \mathrm{M}$ sodium citrate, $\mathrm{pH} 7.0$ ).

Membranes were washed twice with $50 \mathrm{ml}$ of washing buffer I ( 2 x SSC containing $0.1 \%(w / v)$ SDS ) at room temperature for $5 \mathrm{~min}$ and then twice (15 to $30 \mathrm{~min}$ each) in washing buffer II (0.1x SSC and $0.1 \%(w / v)$ SDS) at $68{ }^{\circ} \mathrm{C}$. After hybridisation, the membranes were washed for $30 \mathrm{~min}$ at room temperature with 100 $\mathrm{ml}$ of buffer $\mathrm{A}$ and then for a further 30 min with 100 $\mathrm{ml}$ of blocking reagent diluted 1:10 in buffer A. Antidigoxigenin antibody (Roche,Welwyn Garden City, UK) was then diluted 1:5000 in $20 \mathrm{ml}$ of the same blocking reagent solution and applied to the membrane for $30 \mathrm{~min}$.

After incubation with antibody the membrane was washed twice in buffer A $(100 \mathrm{ml})$ for $15 \mathrm{~min}$ at room temperature and then twice in $0.5 \mathrm{x} \mathrm{SSC}(100 \mathrm{ml})$ for $10 \mathrm{~min}$ at $65^{\circ} \mathrm{C}$. The membranes were then immersed in $20 \mathrm{ml}$ of buffer B $(0.1 \mathrm{M}$ Tris- $\mathrm{HCl}, 0.1 \mathrm{M} \mathrm{NaCl}$ and $0.05 \mathrm{M} \mathrm{MgCl}_{2}, \mathrm{pH} 9.5$ ) for $2 \mathrm{~min}$. Finally, the membranes were incubated in a freshly prepared colour-substrate solution $(200 \mu \mathrm{l}$ of a NBT/BCIP stock solution in $10 \mathrm{ml}$ of buffer $\mathrm{B}$ ), sealed in a plastic box in the dark and incubated for $16 \mathrm{~h}$ at room temperature. The reaction was stopped by washing the membranes 
for $5 \mathrm{~min}$ with $50 \mathrm{ml}$ of water. Membranes were then analysed with an image analyser, using a programme written by Dr L. Richards, King's College London.

\section{Results}

\section{Biochemical studies}

Rates of oxygen uptake with glucose, organic acids, glycerol and ethanol are compared in Table 1 which are expressed as a percentage of the rate observed with lactate $(50 \mu \mathrm{M})$ rather than with glucose. The reason for this was that glucose was not metabolised by all strains. Amongst the eight new strains, strains 19/2 and 4/2 LC and Eritrean strains T3, T7, T9 and T11 were able to metabolise glucose (Table 1).

In contrast, Baringo and 7/1a, were unable to utilise glucose, even at a high concentration of $2.5 \mathrm{mM}$ but rapidly metabolised the organic acids, lactate, pyruvate and 2-oxobutyrate. The ability of strain F38 to oxidise organic acids, but not glucose, was shown. The specific rates of lactate oxidation for the strains studied varied approximately ten-fold with the highest rates being observed for the Eritrean strains (Table 2).

The six glucose oxidising strains were metabolically uniform in that they all: oxidised $\mathrm{N}$-acetylglucosamine, pyruvate and lactate with a high affinity; oxidised mannose, glucosamine and 2-oxybutyrate with a low affinity; and were unable to utilise maltose, trehalose, fructose or ethanol (Table 3).

Also, five of these six strains oxidised glycerol at a high rate and with a high affinity, the exception being strain 19/2 which was unable to oxidise this substrate.

The subsp. capripneumoniae strains unable to oxidise glucose, Baringo, 7/1a, both showed a high affinity for lactate, 2-oxybutyrate and pyruvate (Table 4).

They appeared metabolically similar to the strains, F38, G1943/80, G94/80, studied by Abu-Groun et al. (1994) except with respect to glycerol and ethanol oxidation. The strains studied here oxidised glycerol but not ethanol, whereas the converse was true for strains F38, G1943/80 and G94/80.

\section{Molecular studies}

The results given in Table 5 show DNA-DNA hybridisation values amongst two glucose-oxidising, 4/2 LC, 19/2, and three organic acid-oxidising, F38, $7 / 1 \mathrm{a}$, Baringo, strains. Irrespective of the source of the labelled DNA, hybridisation values were mostly greater for strains belonging to the same biochemical group. The mean hybridisation value within the biochemical groups was $94 \%$, whereas between groups it was $85.5 \%$.

This data therefore suggests that the loss of glucose oxidising ability is associated with a particular evolutionary line within subsp. capripneumoniae. This is also supported by the data of Pettersson et al. (1998) which revealed two major lines of descent amongst subsp. capripneumoniae strains (giving polymorphism patterns I and II). The two glucose oxidising strains used in the study were both typed as possessing a IIB3 polymorphism pattern (Table 6 ).

The organic acid-oxidising strains typed as polymorphism pattern 1A, IIB or IIB2. By DNA-DNA hybridisation, the Baringo strain (pattern IA) appeared more closely related to strain 7/1a (pattern IIB2) than to F38 (pattern IIB).

DNA-DNA hybridisation was also carried out between subsp. capripneumoniae strains and other members of the $M$. mycoides cluster (Table 7).

These experiments used labelled DNA from two representative subsp. capripneumoniae strains; these were 7/1a (organic acid-oxidising) and 4/2 LC (glucose-oxidising). The results showed a particularly close relationship of the glucose-oxidising strain to $M$ leachii strains, with hybridisation values of $88-98 \%$ (mean 94\%; seven strains tested). This relationship was also noted in experiments using labelled DNA from strain B144 P. It is known that $M$. c. capripneumoniae may show strong serological cross reactions with $M$ leachii strains (Kanyi Kibe et al., 1985; Chingi et al., 1987). For the organic acid oxidising strain 7/1a, hybridisation values with $M$ leachii strains were lower (77 - 84\%) and were similar to those with M. mycoides subsp. mycoides strains (76 and 83\%).

\section{Discussion}

In the study of Abu-Groun et al. (1994), only four strains of $M$. c. capripneumoniae were used. One of these oxidised glucose while the remaining three strains (including the type-strain, F38) gave no detectable oxygen uptake with glucose but did oxidise organic acids. These results were surprising since the seven $M$. c. capricolum strains and all of the other M. mycoides cluster strains in the study oxidised glucose. Also, the metabolic diversity within $M . \quad c$. capricolum and particularly within subsp. capripneumoniae was greater than would be expected in a homogeneous taxonomic grouping. Strains unable to utilise glucose presumably differ from glucose-metabolising strains in the possession and/or expression of a wide range of transport proteins and enzymes associated with sugar metabolism and the Embden-Meyerhoff pathway

The data presented in this paper confirm that reported by Abu-Groun et al. (1994). Of the eight new strains studied, six metabolised glucose and two did not. In addition, it was confirmed that the type strain of $M$. $c$. capripneumoniae, F38, also failed to metabolise glucose.

The patterns of substrate utilisation shown by the glucose-metabolising strains were generally similar to one another and to the previously studied strain G183. Amongst the $M$. mycoides cluster, the patterns were most similar to those for M. m. mycoides strains; however, all of the glucose-oxidising subsp. capripneumoniae strains failed to oxidise fructose and had a low affinity for 2-oxybutyrate. 
Table 1. Utilisation of glucose, glycerol and ethanol by M. c. capripneumoniae strains.

\begin{tabular}{|c|c|c|c|c|c|c|c|c|c|c|c|c|}
\hline \multirow{2}{*}{ Substrate } & \multirow{2}{*}{$\begin{array}{l}\text { Concentration } \\
(\mu \mathrm{M})\end{array}$} & \multicolumn{11}{|c|}{ Rate of oxygen uptake (\% rate for lactate) } \\
\hline & & $19 / 2$ & $4 / 2 \mathrm{LC}$ & $\mathrm{T} 3$ & $\mathrm{~T} 7$ & T9 & $\mathrm{T} 11$ & G183 & Baringo & $7 / 1 \mathrm{a}$ & F38 & G94/83 \\
\hline Lactate & 50 & 100 & 100 & 100 & 100 & 100 & 100 & 100 & 100 & 100 & 100 & 100 \\
\hline Pyruvate & 50 & 30 & 22 & 26 & 16 & 15 & 30 & 19 & 75 & 147 & 71 & 217 \\
\hline \multirow{3}{*}{ 2-oxybutyrate } & 40 & $<1 *$ & $<1$ & $<1$ & $<1$ & $<1$ & $<1$ & $<1$ & 69 & 116 & 58 & 191 \\
\hline & 400 & $<1$ & $<1$ & 7 & 2 & 3 & 5.5 & $<1$ & & & & \\
\hline & $4.0 \mathrm{mM}$ & 18 & 16 & 17 & 22 & 25 & & & & & & \\
\hline \multirow{2}{*}{ Glucose } & 25 & 44 & 65 & 39 & 52 & 48 & 23 & 590 & $<1$ & $<1$ & $<1$ & $<1$ \\
\hline & $2.5 \mathrm{mM}$ & & & & & & & & $<1$ & $<1$ & $<1$ & $<1$ \\
\hline \multirow{2}{*}{ Glycerol } & 50 & $<1$ & 72 & 77 & 13 & 79 & 57 & 650 & 85 & 59 & $<1$ & $<1$ \\
\hline & $5.0 \mathrm{mM}$ & $<1$ & & & & & & & & & $<1$ & $<1$ \\
\hline Ethanol & $10 \mathrm{mM}$ & $<1$ & $<1$ & $<1$ & $<1$ & $<1$ & $<1$ & $<1$ & $<1$ & $<1$ & $37 * *$ & 37 \\
\hline
\end{tabular}

$(*):<1$ not detectable $\left(<1 \mathrm{nmol}^{-1} \mathrm{mg}\right.$ cell protein $\left.{ }^{-1}\right) ;(* *)$ : Data from Abu-Groun et al. (1994).

Table 2. Specific rate of lactate oxidation by $M$. $c$. capripneumoniae strains (Initial lactate concentration was 50 $\mu \mathrm{M})$.

\begin{tabular}{|c|c|c|}
\hline Strain & Origin & $\begin{array}{l}\text { Rate of oxygen uptake with lactate } \\
\left(\text { nmol.min }{ }^{-1} \text { cell protein }{ }^{-1}\right)\end{array}$ \\
\hline $19 / 2$ & Oman & 32 \\
\hline $4 / 2 \mathrm{LC}$ & Oman & 29 \\
\hline $\mathrm{T} 3$ & Eritrea & 289 \\
\hline $\mathrm{T} 7$ & Eritrea & 128 \\
\hline T9 & Eritrea & 171 \\
\hline T11 & Eritrea & 160 \\
\hline $7 / 1 \mathrm{a}$ & Turkey & 41 \\
\hline F38 & Kenya & 37 \\
\hline Baringo & Kenya & 45 \\
\hline
\end{tabular}

Table 3. Utilisation of glucose, glycerol and ethanol by $M$ c.capripneumoniae strains.

\begin{tabular}{|c|c|c|c|c|c|c|c|}
\hline \multirow{2}{*}{ Substrate } & \multirow{2}{*}{$\begin{array}{l}\text { Conc. } \\
(\mu \mathrm{M})\end{array}$} & \multicolumn{6}{|c|}{$\begin{array}{l}\text { Rate of oxygen uptake } \\
\text { (\% rate for lactate) }\end{array}$} \\
\hline & & $19 / 2$ & $4 / 2 \mathrm{LC}$ & $\mathrm{T} 3$ & $\mathrm{~T} 7$ & T9 & T11 \\
\hline Lactate & 50 & 100 & 100 & 100 & 100 & 100 & 100 \\
\hline Maltose & $1 \mathrm{nmM}$ & $<1^{*}$ & $<1$ & $<1$ & $<1$ & $<1$ & $<1$ \\
\hline Trehalose & $1 \mathrm{mM}$ & $<1$ & $<1$ & $<1$ & $<1$ & $<1$ & $<1$ \\
\hline Fructose & 25 & $<1$ & $<1$ & $<1$ & $<1$ & $<1$ & $<1$ \\
\hline GlcNAc** & 25 & 19 & 32 & 9 & 28 & 30 & 6 \\
\hline \multirow{3}{*}{ Glucosamine } & 25 & 9 & 15 & 7 & 14 & 8 & 4 \\
\hline & 250 & 31 & 56 & 15 & 25 & NT & NT \\
\hline & $2.5 \mathrm{mM}$ & 58 & 100 & 33 & 43 & NT & NT \\
\hline \multirow{3}{*}{ Mannose } & 25 & $<1$ & $<1$ & 9 & 5 & 16 & 3 \\
\hline & 250 & 5 & 23 & 19 & 11 & NT & NT \\
\hline & $2.5 \mathrm{mM}$ & 34 & 41 & 41 & 25 & NT & NT \\
\hline
\end{tabular}

The non-glucose oxidising subsp. capripneumoniae strains, from both this study and the study of AbuGroun et al. (1994), were also very similar to one another. Interestingly, they all had a high affinity for 2-oxybutyrate. These strains would appear dependent entirely upon organic acids (and possibly glycerol in some strains) for energy generation, and the yield of these strains was increased markedly by pyruvate (data not shown; Miles et al., 1988). It was noted that the Eritrean strains (glucose oxidising) were difficult to grow and that their growth yield in media containing glucose was increased several fold by the addition of pyruvate. Thus, it may be that organic acids are also important energy sources for glucose oxidising strains and that the glucose-catabolising pathway in these strains is not used in vivo for energy generation. All of the glucose oxidising strains (except G183) metabolised organic acids at significantly higher rates than glucose.

The Eritrean strains used in the present study were isolated from outbreaks in goat herds with very high mortality rates (Houshaymi et al., 2002).

All strains metabolised glycerol at a high rate, a feature potentially important in pathogenicity because of the accompanying hydrogen peroxide production which may have accounted for the seriousness of the outbreaks.

However, amongst other isolates, glycerol metabolism varied. Incidently, the high levels of hydrogen production produced by the subsp. capripneumoniae strains, in particular those from Eritrea, compared to other members of the cluster (i.e. typically $1 \mathrm{~mol}$ compared to about 0.05 mol per mol of $\mathrm{O}_{2}$ taken up) may account for their fastidiousness in vitro.

The use of pyruvate in the medium may reduce the impact of $\mathrm{H}_{2} \mathrm{O}_{2}$ production as it may be metabolised to lactate plus acetate without net NADH production. 
Table 4. Kinetics of substrate utilisation by M. c. capripneumoniae strains expressed as saturation constant $\mathrm{Km}(\mu \mathrm{M}) \mathrm{values}$.

\begin{tabular}{|c|c|c|c|c|c|c|c|c|c|}
\hline \multirow{2}{*}{ Substrate } & \multicolumn{9}{|c|}{ Km value $(\mu \mathrm{M})$} \\
\hline & $19 / 2$ & $4 / 2 \mathrm{LC}$ & $\mathrm{T} 3$ & $\mathrm{~T} 7$ & $\mathrm{~T} 9$ & $\mathrm{~T} 11$ & Baringo & $7 / 1 \mathrm{a}$ & G94/83 \\
\hline Glucose & 3.5 & 3.1 & 5.3 & 4.6 & 4.0 & 6.9 & $<1$ & $<1$ & $<1$ \\
\hline GlcNAc* & 1.7 & 2.5 & 1.1 & 1.8 & 2.5 & 0.8 & $<1$ & $<1$ & $<1$ \\
\hline Fructose & $<1$ & $<1$ & $<1$ & $<1$ & $<1$ & $<1$ & $<1$ & $<1$ & $<1$ \\
\hline Glucosamine & 116 & 227 & 96 & 142 & NT & NT & $<1$ & $<1$ & $<1$ \\
\hline Mannose & $5 \mathrm{mM}$ & 526 & 111 & 122 & NT & NT & $<1$ & $<1$ & $<1$ \\
\hline Pyruvate & 13 & 11 & 11 & 12 & 13 & 7 & 14 & 17 & 5.8 \\
\hline Lactate & 8.1 & 7.5 & 14 & 17 & 11 & 18 & 10 & 16 & 4.6 \\
\hline 2-oxybutyrate & $0.4 \ddagger$ & $0.4 \ddagger$ & $2.9 \mathrm{mM}$ & 830 & 740 & 2.2 & 11 & 10 & 9.7 \\
\hline Glycerol & $<1$ & 2.1 & 9.7 & 7.7 & 4.5 & 5.4 & 3.4 & 3.5 & $<1$ \\
\hline
\end{tabular}

(<1): not metabolised; (NT): not tested; (ł): Substrate metabolised detected at $4 \mathrm{mM}$ but not at $0.4 \mathrm{mM}$; $(*)$ : N-acetylglucosamine.

Table 5. DNA-DNA hybridisation between $M . \quad c$. capripneumoniae strains. Data shown are the mean \% hybridisation values from three independent replicate experiments.

\begin{tabular}{lcccc}
\hline $\begin{array}{l}\text { M. c. capripneumoniae } \\
\text { strains }\end{array}$ & F38 & 7/1a & Baringo & $4 / 2$ LC \\
\hline F38 & 100 & NT & NT & 78 \\
7/1a & 92 & 100 & 98 & 92 \\
Baringo & 89 & NT & 100 & 93 \\
4/2 LC & 84 & 86 & NT & 100 \\
19/2 & 8 & 83 & 86 & 98 \\
$\begin{array}{l}\text { Mycoplasma bovis } \\
\text { NCTC 10131* }\end{array}$ & 14 & 9 & 7 & 12 \\
\hline
\end{tabular}

(NT): not tested; $(*)$ : Included as negative control.

Table 6. Comparison of biochemical types and polymorphism patterns of $16 \mathrm{~S}$ rRNA genes in $M$. capricolum subsp. capripneumoniae.

\begin{tabular}{lcc}
\hline Strain & $\begin{array}{c}\text { Polymorphism } \\
\text { pattern* }\end{array}$ & Biochemical type \\
\hline F38 & IIB & Oxidises organic acids \\
\hline $7 / 1$ a & IIB2 & Oxidises organic acids \\
\hline $4 / 2$ LC & IIB3 & Ferments glucose \\
\hline $19 / 2$ & IIB3 & Ferments glucose \\
\hline Baringo & IA & Oxidises organic acids \\
\hline G1943/80 & IA & Oxidises organic acids \\
\hline G94/83 & IA & Oxidises organic acids \\
\hline (*): Pettersson et al $(1998)$ & \\
\hline
\end{tabular}

Table 7. DNA-DNA hybridisation between $M . \quad c$. capripneumoniae strains (7/1a and 4/2 LC) and other members of the $M$. mycoides cluster. Data shown are the mean $\%$ hybridisation values from three independent replicate experiments.

\begin{tabular}{lll}
\hline Strain & $7 / 1 \mathrm{a}$ & $4 / 2 \mathrm{LC}$ \\
\hline M. c. capripneumoniae & & \\
\hline 7/1a & 100 & \\
4/2 LC & & 100 \\
\hline M. leachii & & \\
\hline PG50 (NCTC 10133) & 82 & \\
QR1 & & 98 \\
B144P & 77 & 94 \\
\hline 4055 & 84 & 91 \\
\hline D318b & & 88 \\
\hline D424 & & 98 \\
\hline C2306 & & 96 \\
Calf 1 & & 92 \\
\hline M. mycoides subsp. mycoides & & \\
\hline PG1 (NCTC 10114) & & 78 \\
\hline Gladysdale & 76 & 79 \\
\hline 4813 & & 79 \\
\hline KH3J & 83 & 77 \\
\hline M. mycoides subsp. capri & & \\
\hline Y goat & 74 & 81 \\
\hline LC 1176-2 & 80 & 71 \\
\hline G108 & 70 & 75 \\
\hline Pendik & 75 & 68 \\
\hline M. bovis (-ve control) & & \\
\hline NCTC 10131 & & \\
\hline & & \\
\hline
\end{tabular}


Furthermore, $\mathrm{H}_{2} \mathrm{O}_{2}$ has been identified as a pathogenicity factor (via the oxidation of glycerol) in the closely related $M$. mycoides subsp mycoides in which the virulent African strains but not the largely non-virulent European strains are strong producers (Houshaymi et al., 1997). The Eritrean strains were from a particularly severe outbreak in which mortality rates were particularly high.

Whole genome DNA-DNA hybridisation techniques have been widely used to assess taxonomic relationships amongst cell-walled bacterial groups and have been of fundamental importance in establishing many new species and genera.

They have also been used in a number of studies with mycoplasmas, for example: the classification of spiroplasmas (Townsend et al., 1977; Lee and Davis, 1980); the demonstration of the relationship between $M$. fermentans and the organism originally referred to as $M$. incognitus (Saillard et al., 1990); the establishment of $M$. imitans as a distinct species, despite its very similar rRNA sequence with $M$. gallisepticum (Johnson, 1984; Dupiellet et al., 1988, 1990); the separation of $M$. bovis from the metabolically similar $M$. agalactiae (M. bovis was previously regarded as a variety of $M$. agalactiae) (Askaa and Ernø, 1976); and in studies of the $M$. mycoides cluster.

In general, DNA-DNA hybridisation studies have shown a close overall relationship between members of the cluster (Askaa et al., 1978; Christiansen and Ernø, 1982; Bonnet et al., 1993). However, M. c. capricolum, M. leachii and $M$. F38-like strains were more closely related to each other than to $M$. mycoides subsp. capri strains (International Committee, 1991; Bonnet et al., 1993). The close relationship between $M$. F38-like strains and M. c. capricolum (70 and $78 \%$ under high and low stringency conditions, respectively), led to the renaming of $M$. F38-like strains as $M . \quad c$. capripneumoniae (Bonnet et al., 1993; Leach et al., 1993).

Mycoplasma Identification is based on the general species definition using a combination of serology and phenotypic data, 16S rRNA gene sequence analyses and DNA-DNA hybridization (Brown et al., 2007). The advantage of DNA-DNA hybridisation in taxonomic studies is that it provides an overall indication of the DNA-relatedness of organisms. While $16 \mathrm{~S}$ rRNA gene sequence analysis is rapid it can provide ambiguous results because mycoplasma species may have up to $100 \%$ gene similarity. For instance, the pairs $M$. pneumoniae and M. genitalium, M. mycoides and M. c. capricolum have $98 \%$ and $99.8 \% 16 \mathrm{~S}$ rRNA sequence similarity, respectively. Serology is also very cumbersome, requiring a large selection of hyperimmune sera and the expertise of few international laboratories. In addition, the serological tests may result in cross-reaction between species because of the high genomic and phenotypic diversity of Mycoplasmas (Thompson et al., 2012).

DNA appears particularly suitable in studies of closely related groups, for example the members of the $M$. mycoides cluster (Cottew et al., 1987), which show few differences in their 16S rRNA nucleotide sequences (Fox et al., 1992). However, compared to many molecular biology techniques, traditional methods for determining DNA-DNA hybridisation are laborious, requiring large quantities of DNA. In addition, detection of hybrid DNA requires that one DNA source is labelled; this was generally achieved by growth of cells using $\left[{ }^{3} \mathrm{H}\right]$ or $\left[{ }^{14} \mathrm{C}\right]$-labelled substrates. Non radioactive labels are of course available today.

In conclusion $M$. c. capripneumoniae strains show a high overall DNA homology, but that nevertheless, the group may be subdivided and the subdivision is consistent with the two biotypes, glucose and organic acid oxidising, determined from biochemical studies. These two groups of strains presumably differ in the possession and/or expression of a substantial range of transport proteins and enzymes associated with sugar metabolism via the Embden-Meyerhoff pathway. Such fundamental metabolic diversity is not usually seen amongst members of the same species and therefore, DNA-DNA hybridisation studies were carried out. The results showed that although the two groups of strains could be separated by their degree of DNA homology, the mean hybridisation value between members of the two groups was $86 \%$ well within the value of $70 \%$ normally used to indicate separate species. We encourage other molecular biologists to investigate our findings using the many tools available today to see whether further subdivision is possible.

The relatively high DNA homology of $M . c$. capripneumoniae with subsp. capricolum has already been reported (Bonnet et al., 1993; Christiansen and Ernø, 1982). However, there is also a particularly close relationship between glucose oxidising subsp. capripneumoniae strains and M. leachii strains.

\section{Acknowledgements}

We are indebted to the late Dr Roger Miles whose wisdom and humanity guided this work.

\section{Conflict of interest}

The authors declare that there is no conflict of interest.

\section{References}

Abu-Groun, E.A.M., Taylor, R.R., Varsani, H., Wadher, B.J., Leach, R.J. and Miles, R.J. 1994. Biochemical diversity in the ' $M$. mycoides' cluster. Microbiol. 140, 2033-2042.

Askaa, G. and Ernø, C. 1976. Elevation of Mycoplasma agalactiae subsp. bovis to species rank: Mycoplasma bovis (Hale et al.) comb. nov. Int. J. Syst. Bacteriol. 26, 323-325. 
Askaa, G., Ernø, H. and Ojo, M.O. 1978. Bovine mycoplasmas: classification of groups related to Mycoplasma mycoides. Acta Vet. Scandinavica 19, 166-178.

Bashiruddin, J.B. 1998 Extraction of DNA from mycoplasmas. In: Methods in Molecular Biology: Mycoplasma Protocols. Edited by: R.J. Miles and R.A.J. Nicholas, Humana Press, Totowa, New Jersey, Vol. 104, pp: 141-145.

Bonnet, F., Saillard, C., Bové, J.M., Leach, R.H., Rose, D.L., Cottew, G.S. and Tully, J.G. 1993. DNA relatedness between field isolates of Mycoplasma F38 group, the agent of contagious caprine pleuropneumonia, and strains of Mycoplasma capricolum. Int. J. Syst. Bacteriol. 43, 597-602.

Brown, D.R., Whitcomb, R.F. and Bradbury, J.M. 2007. Revised minimal standards for description of new species of the class Mollicutes (division Tenericutes). Int. J. Syst. Evol. Microbiol. 57, 27032719.

Chingi, A.K., Ernø, H. and Waiyaki, P.G. 1987. Report on serological problems in classification of mycoplasmas from cases of contagious caprine pleuropneumonia in Kenya. In: Agriculture : contagious agalactia and other mycoplasmal diseases of small ruminants. Edited by: G.E. Jones. Office for Official Publications on the European Communities, Luxembourg, pp: 85-89.

Christiansen, C. and Ernø, H. 1982. Classification of the F38 group of caprine mycoplasma strains by DNA hybridization. J. Gen. Microbiol. 128, 25232526.

Cottew, G.S., Breard, A., DaMassa, A.J., Ernø, H., Leach, R.H., Lefevre, P.C., Rodwell, A.W. and Smith, G.R. 1987 Review Taxonomy of the Mycoplasma mycoides cluster. Isr. J. Med. Sci. 23, 632-635.

Dupiellet, J.-P., Vuillaume, A., Rousselot, D., Bové, J.M. and Bradbury, J.M. 1990. Serological and molecular studies on Mycoplasma gallisepticum strains. Zentralblatt Für Bakteriologie Suppl. 20, 859-864.

Dupiellet, J.-P., Vuillaume, A., Rousselot, D., Bové, J.M. and Bradbury, J.M. 1988. Serological and molecular studies on Mycoplasma gallisepticum strains. $7^{\text {th }}$ Congress. International Organisation of Mycoplasmology Conference. Abstract, pp: 150.

Fox, G.E, Wisotzkey, J.D. and Jurtshuk Jr, P. 1992. How close is close: 16S rRNA sequence identity may not be sufficient to guarantee species identity. Int J. Syst. Bacteriol. 42, 166-170.

Houshaymi, B.M., Miles, R.J. and Nicholas, R.A.J. 1997. Oxidation of glycerol differentiates African from European isolates of Mycoplasma mycoides subspecies mycoides SC (small colony). Vet. Rec. 140, 182-183.
Houshaymi, B.M., Miles, R.J. and Nicholas, R.A.J. 2002. Studies on strains of Mycoplasma capricolum subsp. capripneumoniae isolated from outbreaks of contagious caprine pleuropneumonia. Small Rum. Res. 45, 139-143.

International Committee. 1991. International Committee on Systematic BacteriologySubcommittee on the Taxonomy of Mollicutes. Int. J. Syst. Bacteriol. 41, 333-336.

Johnson, J.L. 1984. Bacterial classification. III. Nucleic acids in bacterial classification. In Bergey's Manual of Systematic Bacteriology. Edited by: N.R. Krieg and J.G. Holt. Williams and Wilkins, Baltimore, Vol. 1, pp: 8-11.

Kanyi Kibe, M., Bidwell, D.E., Turp, P. and Smith, G.R. 1985. Demonstration of cross-reactive antigens in F38 and related mycoplasmas by enzyme linked immunosorbent assay (ELISA) and immunoblotting. J. Hygiene (Cambridge) 95, 95106.

Leach, R.H., Ernø, H. and MacOwan, K.J. 1993. Proposal for designation of F38-type caprine mycoplasmas as Mycoplasma capricolum subsp. capripneumoniae subsp. nov. and consequent obligatory relegation of strains currently classified as $M$. capricolum (Tully, Barile, Edward, Theodore, and Ernø 1974) to an additional new subspecies, $M$. capricolum subsp. capricolum subsp. nov. Int. J. Syst. Bacteriol. 43, 603-605.

Lee, I.-M. and Davis, R.E. 1980. DNA homology among diverse spiroplasma strains representing several serological groups. Can. J. Microbiol. 26, 1356-1363.

Manso-Silvan, L., Perrier, X. and Thiaucourt, F. 2007. Phylogeny of the Mycoplasma mycoides cluster based on analysis of five conserved protein-coding sequences and possible implications for the taxonomy of the group. Int. J. Syst. Evol. Microbiol. 57, 2247-2258.

Miles, R.J., Wadher, B.J., Henderson, C.L. and Mohan, K. 1988. Increased growth yields of Mycoplasma species in the presence of pyruvate. Letters App. Microbiol. 7, 149-151.

Miles, R.J. and Agbanyim, C. 1998. Determination of substrate utilisation rates by mycoplasmas. In Methods in Molecular Biology: Mycoplasma Protocols. Edited by R.J. Miles and R.A.J. Nicholas, Humana Press, Totowa, New Jersey, Vol. 104, pp: 95-104.

Pettersson, B., Bölske, G., Thiaucourt, F., Uhlén, M. and Johansson, K.-E. 1998. Molecular evolution of Mycoplasma capricolum subsp. capripneumoniae strains, based on polymorphisms in the $16 \mathrm{~S}$ rRNA genes. J. Bacteriol. 180, 2350-2358.

Saillard, C., Carle, P., Bové, J.M., Bébéar, C., Lo, S.C., Shih, J.W.-K., Wang, R.Y.-H., Rose, D.L. and 
Tully, J.G. 1990. Genetic and serologic relatedness between $M$. fermentans strains and mycoplasma recently identified in tissues of AIDS and nonAIDS patients. Res. Virol. 141, 385-395.

Thiaucourt, F., Manso-Silvan, L., Salah, W., Barbe, V., Vacherie, B., Jacob, D., Breton, M., Dupuy, V., Lomenech, A.M., Blanchard, A. and Sirand-Pugnet, P. 2011. Mycoplasma mycoides, from "mycoides Small Colony" to "capri". A microevolutionary perspective. BMC Genomics 12, 114.

Thompson, C.C., Vieira, N.M., Vicente, A.C. and Thompson, F.L. 2012. Towards a genome based taxonomy of Mycoplasmas. Infect. Genet. Evol. 11, 1798-1804.

Townsend, R., Markham, P.G., Plaskitt, A.k. and Daniels, M.J. 1977. Isolation and characterization of Non-Helical strain of Spiroplasma citri. J. Gen. Microbiol. 100, 15-21. 